\title{
Diversity of arthropods regarding habitat specialty in agro-ecosystem of Faisalabad, Pakistan
}

\author{
Rana Naureen ${ }^{1}$, Saleem Maryam ${ }^{1}$, Majeed Waqar ${ }^{1, *}$, Jalal Fatima ${ }^{2}$, Ehsan Nazia ${ }^{1}$ and Nargis Shahla ${ }^{1}$ \\ ${ }^{1}$ Department of Zoology, Wildlife and Fisheries, Faculty of Sciences, University of Agriculture, Faisalabad, Pakistan. \\ 2 Department of Zoology, GCU, Faisalabad, Pakistan.
}

Publication history: Received on 16 January 2019; revised on 05 February 2019; accepted on 07 February 2019

Article DOI: https://doi.org/10.30574/gscbps.2019.6.2.0008

\begin{abstract}
Biodiversity is a measurement of the variety of organisms within species present in an ecosystem and can refer to ecosystem variation, genetic variation and species variation within a biome. They consist of diversity, evenness, dominance and richness of inhabiting taxa in that area. This study was carried out to check the diversity of different arthropods among crops and fields of District Faisalabad, Punjab, Pakistan. Total 1088 specimens were collected belonging to 8 orders, 24 families, 35 genera and 38 species from agro- ecosystem. So, keeping in view the importance of these aspects, calculations were made as per Shannon Diversity Index and SPDIVERS.BAS software. Diversity (H) was recorded as (1.2720), while Diversity мax. $\left(\mathrm{H}^{\prime}{ }_{\max }\right)$ was recorded (3.0366). Evenness was (0.0896) while dominance was (1.0896). The value for richness was recorded as (11.6423). To highlight their major distribution and contribution, relative abundance was recorded maximum for genus Drosophila $60.85 \%(\mathrm{~N}=662)$, followed by Musca $7.17 \%(\mathrm{~N}=78)$, Chamaepsila 6.34\% ( $=69)$, Hippodamia 5.15\% ( $=56)$, Sepsis 4.14\% ( $=45)$, Culex 2.67\% ( $=29)$, Episyrphus 1.56\% $(\mathrm{N}=17)$, Coccinella 1.38\% ( $=15)$, Aedes, xestia 1.19\% ( $=13)$, Camnula, Omocestus $0.92 \%(\mathrm{~N}=10)$, Cheilomenes $0.83 \%(\mathrm{~N}=9)$, Aleiodes, Anchastus $0.64 \%(\mathrm{~N}=7)$ and zizula $0.55 \%(\mathrm{~N}=6)$. However, least relative abundance $(\mathrm{N} \leq 5)$ was recorded for Ochlerotatus, Nemopoda, Eupeodes, Sphaerophoria, Chrysotoxum, Culicoides, Chrysoperla, Acrida, Scudderia, Gigantiops, Ancistrocercus, Byturus, Leptinotarsa, Dyscinetus, Haploa, Oncopeltus, Cimex, Araniella and Argiope.
\end{abstract}

Keywords: Diversity; Arthropods; Abundance; Agro-ecosystem; Musca; Chamaepsila

\section{Introduction}

An ecological sphere having plantation, animal and other type of organisms is inhabited is called biosphere. It defines as zone where the organisms can live and finds all ecological resources such as protection, shelter, food and mates for reproduction [1]. Habitat specialization defines the degree of isolation of population and the ability of species to disperse, so it is considered as very important determinants of species vulnerability for fragmentation and habitat loss. Moreover, the species dispersal success in a particular habitat depends on distance between fragments that is conditioned landscape from total amount of habitat [2]. Biodiversity is a measure of the variety of organisms within species and between species present in an ecosystem. This can refer to ecosystem variation, genetic variation and species variation within a biome, area and planet [3]. Biodiversity also provides many useful ecosystem services and goods including maintenance of habitats for beneficial insects and pollinators, nutrient recycling and reducing soil water runoff [4].

Phylum Arthropoda is the largest and most important group of Kingdom Animalia. Worldwide, the phylum Arthropoda contains an estimated 2 million to 50 million specie [5]. Some of the more well-known arthropods include insects,

\footnotetext{
${ }^{*}$ Corresponding author

E-mail address: waqarchaudhry20@gmail.com
} 
crustaceans and spiders, as well as the mollusks [6]. Arthropods account for the largest percentage of animal biomass and biodiversity in the agro-ecosystem [7]. Arthropods play a vital role in ecosystem services as pollinators, predators, decomposers and nutrient recycler and their quick responses to ecological changes make them potentially good bioindicators [8]. Predators are remarkably beneficial and affect the guilds diversity of other invertebrate in agroecosystems because they help to suppress and regulate phytophagous pest populations [9, 10, 11]. For example, members of insect orders like coleoptera and neuroptera have been used as bio control agents [12]. They help the humans directly and indirectly as providing food and as pollinators. These factors showed that they are most importantly used in agricultural and ecological research studies and compare intercropping agro-forestry in terms of biological diversity and sustainability.

Approximately one quarter of all insect species are phytophagous and play a crucial role in agro-ecosystems as consumers of plants and as food for predators [13]. The members of Hymenoptera, Diptera, Thysanoptera, Lepidoptera, Phasmida, Orthoptera, Hemiptera, Demaptera, Coleoptera, Hornoptera and Lepidoptera are naturally herbivores [14, 15]. Although, they are generally considered as pests and biocontrol agents of weeds within an agro-ecosystem [16]. On the other side, they are considered as vector and pest that transmit a huge number of diseases and are responsible for global crop losses of almost $20-50 \%$ of potential production, respectively. These diseases have hazardous effects on human population [17].

Community of biotic components linked with abiotic components of their surrounding or environment (abiotic factors like water, mineral soil and air) act as a system called an ecosystem. However, their nature differs as per their characteristics (desert, aquatic, terrestrial, forests, wetlands and agro-ecosystems etc.). The function of ecosystem is the mixture of ecosystem goods, services and properties [18]. In agro-ecology, the fundamental unit of study is an agroecosystem that is subjectively defined as functionally and spatially coherent unit of activity of agriculture system which is also includes the biotic and abiotic components and their interactions [19].

Agro-ecosystem is composed of socio economic dimensions, in which human introduced a well plan selective composition of biota such as livestock and crops maintained by the farmers, by replacing smaller and larger amount of the natural biodiversity of location [20]. Agriculture is the backbone of the economy of Pakistan. They are key motor of the universal economy covering about $28 \%$ of all land with $38 \%$ in the temperate, $38 \%$ in the tropical and $23 \%$ in the subtropical regions. In Pakistan, the total Geographical area is 79.6 million hectares, from this agriculture land covers $27 \%$ of total surface area [21]. Agriculture dependent population is $75-80 \%$ from which the gross domestic product included $30 \%$. In an agro-ecosystem, the amount of disturbance varies significantly in the conditions of intensity, frequency and types of interruption. The main disturbances are application of pesticides and herbicides, and tillage operations to manage insect pests and crop harvest. Particularly, Vegetable production systems are greatly disturbed because of short crop cycles sometimes with multiple crops per year, regular tillage and usually higher fertilizer and pesticide use [22]. So, keeping in view the ecological interaction of arthropods with agro-ecosystem; the present study was proposed to find: The diversity and relative abundance of arthropods among agro-ecosystem.

\section{Material and methods}

\subsection{Study area}

Present study was conducted in the agricultural fields of different crops in district Faisalabad, Punjab, Pakistan in 2016 and study was consisting of rolling flat plains, between longitude $73^{\circ} 74 \mathrm{E}$, latitude $30^{\circ} 31.5^{\circ} \mathrm{N}$, with an elevation of 184 meters (604 ft) above sea level including area $58.56 \mathrm{~km}^{2}$. Vegetation was consisting of different herbs/ shrubs, grasses and different crops: Triticum aestivum, Brassica compestris, Trifolium alexandrium and Saccharum officinarum.

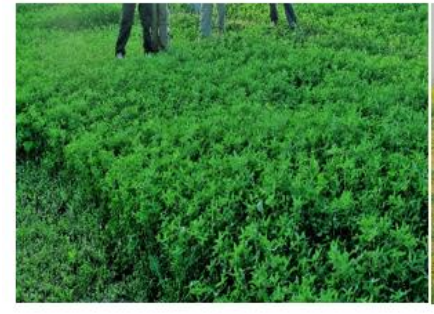

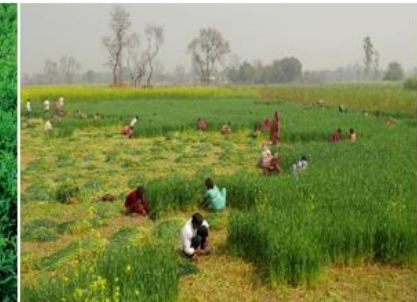

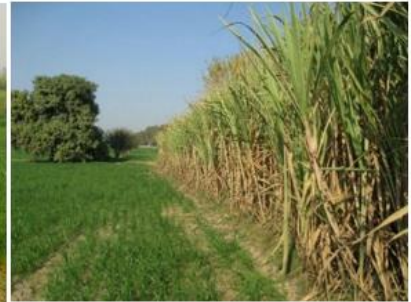

$\mathrm{C}$

Figure 1 Vegetaion of A) Trifolium alexandrium B) Triticum aestivum and Brassica compestris crops C) Saccharum officinarum crop 


\subsection{Collection of data}

To collect the arthropods fauna from sampling sites, sample were made weekly (12 weeks) for two hours from 6:00 am to 8:00 am by following methods: Direct hand picking, by using Sweep Net and by using Forceps. Total 1088 specimens were collected, and specimens were stored in jars containing 70:30\% alcohol and glycerin solution and thereafter collected specimens were shifted to Biodiversity Laboratory, Department of Zoology, Wildlife and Fisheries, University of Agriculture, Faisalabad for further systematic studies. Here, the specimens were separated and preserved in separate glass vials, containing 70:30\% alcohol and glycerin solution for further identification. The glass vials were labeled as sampling number, canal name and with time of day of sampling. The collected specimens were identified and sorted with the aid of naked eye, magnifying glass and microscope. The identifications were conducted based on morphological characters. All the specimens were identified up to species level according to the taxonomic/ reference material [23].

\subsection{Statistical analysis}

Thereafter, all the observed specimens were arranged in table form according to their morphological and taxonomic characters e.g. order, family, genus and species. To determine the various aspects of diversity, Shannon Diversity Index was used [24]

Where $p_{i}$ is the proportion of individuals found in the $i$ th species. The value of $p_{i}$ is estimated as $n_{i} / N$.

\subsubsection{Maximum Diversity}

$$
H_{\max }=-\sum_{i=1}^{S} \frac{1}{S} \ln \frac{1}{S}=\ln S
$$

\subsubsection{Evenness "Hill's Modified Ratio (E)" [25]}

$$
E=\frac{\left(\frac{1}{\bar{\chi}}\right)}{e^{H-1}}=\frac{N^{2-1}}{N^{1-1}}
$$

Where, $E$ is the index of evenness, $\lambda$ is the Simpson's index of diversity and N1 and N2 are the number of abundant and very abundant species respectively in the sample. The richness, diversity and evenness indices were computed by using the Program SPDIVERS.BAS.

\subsubsection{Richness}

$$
S=n+\left(n-\frac{1}{n}\right)^{k}
$$

Where, $\mathrm{S}=$ species richness, $\mathrm{n}=$ total number of species present in sample population, $\mathrm{k}=$ number of "unique" species (of which only one organism was found in sample population).

\subsubsection{Dominance}

$$
\mathrm{D}=1-\mathrm{E}
$$

Where, "E" is evenness.

\section{Results and discussion}

After completing the whole research trials as per methodology, total 1088 specimens were collected belonging to 8 orders, 24 families, 35 genera and 38 species (Table 1). Arthropods were observed in agro-ecosystem Brassica Juncea and Brassica napus from (Multan, Dera ghazi khan and Bahawalpur) Punjab on weekly basis. During the study no arthropods other than insects were observed. As the most abundant among all insects observed Lipaphis erysimi, Brevicoryne brassicae (L.), Myzus persicae on B. juncea and B. napus. Other insects that were recorded includes the whitefly, Bemisia tabaci (Hemiptera), Athalia lugens (Hymenoptera), Spodoptera litura L. and Helicoverpa armigera (Lepidoptera), Neuroptera and Coleoptera were observed [26]. Abundance and composition of arthropod were studied in the aboveground and guild structure in upland rice agro-ecosystem at Matalam, North Cotabato, Philippines. By using direct counting techniques and sweep netting sampling. A total of 29 arthropod species were documented that was belonging to 21 families in nine orders [27]. 
Table 1 Overall taxa composition among agro-ecosystem

\begin{tabular}{|l|l|}
\hline Category & Frequency \\
\hline Order & 8 \\
\hline Families & 24 \\
\hline Genera & 35 \\
\hline Species & 38 \\
\hline
\end{tabular}

Table 2 Overall relative abundance of recorded species among agro-ecosystem

\begin{tabular}{|c|c|c|c|}
\hline Order & Family & Species & Relative abundance (\%) \\
\hline \multirow{16}{*}{ Diptera } & Muscidae & Musca domestica & $7.17(78)$ \\
\hline & \multirow{4}{*}{ Drosophilidae } & Drosophila melanogaster & $4.14(45)$ \\
\hline & & Drosophila funebris & $27.57(300)$ \\
\hline & & Drosophila hydei & $28.68(312)$ \\
\hline & & Drosophila suzukii & $0.46(5)$ \\
\hline & \multirow{3}{*}{ Culicidae } & Culex pipiens & $2.67(29)$ \\
\hline & & Aedes abserratus & $1.19(13)$ \\
\hline & & ochlerotatus triseriatus & $0.09(1)$ \\
\hline & \multirow{2}{*}{ Sepsidae } & Sepsis fulgens & $4.14(45)$ \\
\hline & & Nemopoda nitidula & $0.28(3)$ \\
\hline & \multirow{4}{*}{ Syrphidae } & Episyrphus balteatus & $1.56(17)$ \\
\hline & & Eupeodes corolla & $0.09(1)$ \\
\hline & & Sphaerophoria scripta & $0.09(1)$ \\
\hline & & Chrysotoxum festivum & $0.46(5)$ \\
\hline & Psilidae & Chamaepsila rosae & $6.34(69)$ \\
\hline & Ceratopogonidae & Culicoides impunctatus & $0.09(1)$ \\
\hline Neuroptera & Chrysopidae & Chrysoperla carnea & $0.09(1)$ \\
\hline \multirow{4}{*}{ Orthoptera } & \multirow{3}{*}{ Acrididae } & Acrida conica & $0.28(3)$ \\
\hline & & Camnula pellucida & $0.92(10)$ \\
\hline & & Omocestus viridulus & $0.92(10)$ \\
\hline & Tettigoniidae & Scudderia mexicana & $0.09(1)$ \\
\hline \multirow{3}{*}{ Hymenoptera } & Formicidae & Gigantiops destructor & $0.18(2)$ \\
\hline & Braconidae & Aleiodes indiscretus & $0.64(7)$ \\
\hline & vespidae & Ancistrocercus antilope & $0.18(2)$ \\
\hline \multirow{7}{*}{ Coleoptera } & \multirow{3}{*}{ Coccinellidae } & Coccinella septempunctata & $1.38(15)$ \\
\hline & & Hippodamia tredecimpunctata & $5.15(56)$ \\
\hline & & Cheilomenes sexmaculata & $0.83(9)$ \\
\hline & Byturidae & Byturus unicolor & $0.09(1)$ \\
\hline & Chrysomelidae & Leptinotarsa decemlineata & $0.46(5)$ \\
\hline & Scarabaeidae & Dyscinetus morator & $0.37(4)$ \\
\hline & Elateridae & Anchastus binus & $0.64(7)$ \\
\hline \multirow{3}{*}{ Lepidoptera } & Lycaenidae & Zizula hylax & $0.55(6)$ \\
\hline & Noctuidae & Xestia baja & $1.19(13)$ \\
\hline & Arctiidae & Haploa reversa & $0.09(1)$ \\
\hline \multirow{2}{*}{ Hemiptera } & Lygaeidae & Oncopeltus fasciatus & $0.28(3)$ \\
\hline & Cimicidae & Cimex lectularius & $0.18(2)$ \\
\hline \multirow{2}{*}{ Araneae } & \multirow{2}{*}{ Araneidae } & Araniella cucurbitina & $0.37(4)$ \\
\hline & & Argiope aurantia & $0.09(1)$ \\
\hline \multicolumn{3}{|l|}{ Total } & 1088 \\
\hline
\end{tabular}


From the overall data (Table 2), Drosophila hydei (Diptera: Drosophilidae) was recorded as an extraordinary contributing species with relative abundance of $28.68 \%(\mathrm{~N}=312)$, followed by Drosophila funebris (Diptera: Drosophilidae) 27.57\% ( $=300$ ), Musca domestica (Diptera: Muscidae) 7.17\% (N = 78), Chamaepsila rosae (Diptera: Psilidae) 6.34\% ( $\mathrm{N}=69)$, Hippodamia tredecimpunctata (Coleoptera: Coccinellidae) 5.15\% ( $=56$ ), Drosophila melanogaster (Diptera: Drosophilidae), Sepsis fulgens (Diptera: Sepsidae) 4.14\% (N = 45), Culex pipiens (Diptera: Culicidae) 2.67\% ( $\mathrm{N}=29)$, Episyrphus balteatus (Diptera: Syrphidae) $1.56 \%(\mathrm{~N}=17)$, Coccinella septempunctata (Coleoptera: Coccinellidae) 1.38\% ( $=15)$, Aedes abserratus (Diptera: Culicidae), Xestia baja (Lepidoptera: Noctuidae) $1.19 \%(\mathrm{~N}=13)$, Camnula pellucida (Orthoptera: Acrididae), Omocestus viridulus (Orthoptera: Acrididae) $0.92 \%(\mathrm{~N}=10)$, Cheilomenes sexmaculata (Coleoptera: Coccinellidae) 0.83\% ( $=9$ ), Aleiodes indiscretus (Hymenoptera: Braconidae), Anchastus binus (Coleoptera: Elateridae) 0.64\% ( $\mathrm{N}=7$ ) and Zizula hylax (Lepidoptera: Lycaenidae) 0.55\% (N = 6). However, least relative abundance $(\mathrm{N} \leq 5)$ was recorded for Drosophila suzukii (Diptera: Drosophilidae), Ochlerotatus triseriatus (Diptera: Culicidae), Nemopoda nitidula (Diptera: Sepsidae), Eupeodes corollae (Diptera: Syrphidae), Sphaerophoria scripta (Diptera: Syrphidae), Chrysotoxum festivum (Diptera: Syrphidae), Culicoides impunctatus (Diptera: Ceratopogonidae), Chrysoperla carnea (Neuroptera: Chrysopidae), Acrida conica (Orthoptera: Acrididae), Scudderia mexicana (Orthoptera: Tettigoniidae), Gigantiops destructor (Hymenoptera: Formicidae), Ancistrocercus antelope (Hymenoptera: Vespidae), Byturus unicolor (Coloeptera: Byturidae), Leptinotarsa decemlineata (Coleoptera: Chrysomelidae), Dyscinetus morator (Coleoptera: Scarabaeidae), Haploa reversa (Lepidoptera: Arctiidae), Oncopeltus fasciatus (Hemiptera: Lygaeidae), Cimex lectularius (Hemiptera: Cimicidae), Araniella cucurbitina (Araneae: Araneidae) and Argiope aurantia (Araneae: Araneidae).

The orders with respect to the number of individuals in the different sites were as follows: Diptera (42\%), Coleoptera (18\%), Orthoptera (11\%), Hymenoptera and lepidoptera (8\%), Hemiptera and Araneae (5\%) and Neuroptera (3\%). A maximum number of species was recorded that belonged to order Diptera and others respectively and these species were found in the both sites (Figure 2). Total number of specimens recorded belonging to different orders: Diptera $(\mathrm{N}=925)$, Coleoptera $(\mathrm{N}=97)$, Orthoptera $(\mathrm{N}=24)$, Hymenoptera $(\mathrm{N}=11)$ Lepidoptera $(\mathrm{N}=20)$, Hemiptera $(\mathrm{N}=5)$ and Araneae $(\mathrm{N}=5)$ and Neuroptera $(\mathrm{N}=1)$. Highest number is recorded for the dipterans (Figure 3). This trend has also been recorded previously, Insect diversity in the mangroves of Andaman and Nicobar Islands of India, reported the following results: Lepidoptera 50\%; Coleoptera 20\%; Hemiptera 15\%; Diptera 5\%; Hymenoptera 3\%; Orthoptera, 5\%; Thysanoptera, 2\% [28].

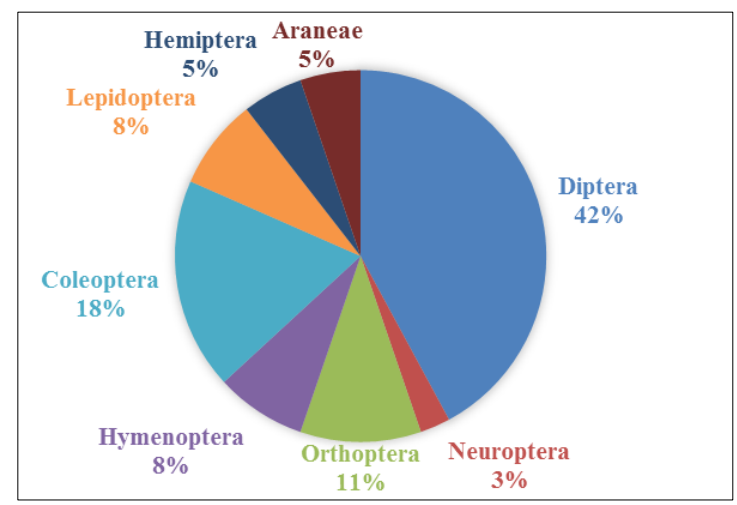

Figure 2 Diversity of species among orders in agro-ecosystem

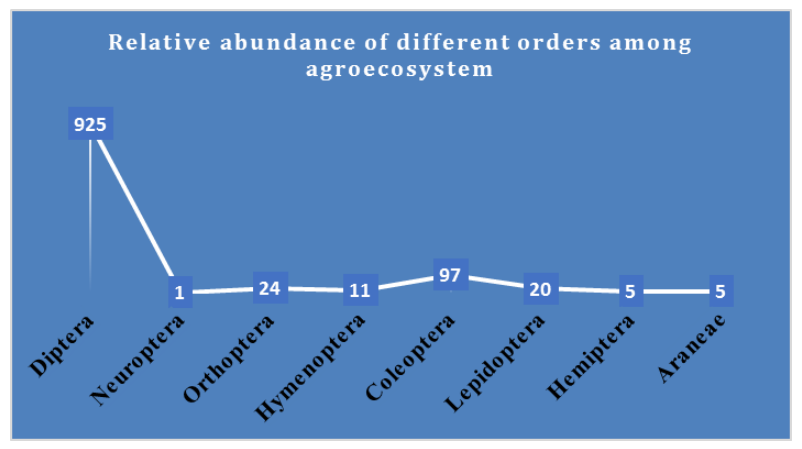

Figure 3 Relative abundance of recorded numbers up to order level among agro-ecosystem 
Diversity indices are key components to draw the natural lines regarding taxa composition pertaining to any managed or unmanaged landscaping. They consist of diversity, evenness, dominance and richness of inhabiting taxa in that area. So, keeping in view the importance of these aspects, calculations were made as per Shannon Diversity Index [29]. In the discussion of future direction, it may be assumed that the region has diversity of described orders and these results may help in the proceeding of research for further work. Different other techniques and methodologies may be directed to evaluate better results. Diversity $(\mathrm{H})$ was recorded as $(1.2720)$, while Diversity Max. $_{\left(\mathrm{H}^{\prime}{ }_{\max }\right)}$ was recorded (3.0366). Evenness was (0.0896) while dominance was (1.0896). The value for richness was recorded as (11.6423) (Table 3). Seasonal abundance was calculated using the Shannon Wiener index, and a minimum value was found during summer. Species richness was calculated using the Margalef index, and we found that, among the three stations, Pichavaram has higher species richness and evenness (based on Pielou's index), as indicated by data from different seasons. In the present study, a marked variation in diversity indices was observed between the stations. In Station I, species diversity varied from 4.950 to 3.692. Species richness fluctuated between 4.478 and 7.955. As regards species evenness, it varied from 0.999 to 0.997 . The taxonomic diversity and total phylogenetic diversity fluctuated from $90 \%$ to $30 \%$. Species richness, population density, and species diversity of terrestrial insects in Uttaranchal were calculated by [30].

Table 3 Diversity indices recorded from Agro-ecosystem

\begin{tabular}{|l|l|}
\hline Diversity indices & Values \\
\hline Diversity $\left(\mathrm{H}^{\prime}\right)$ & 1.2720 \\
\hline Diversity Max $\left(\mathrm{H}^{\prime}{ }_{\text {max }}\right)$ & 3.0366 \\
\hline Evenness $(\mathrm{J})$ & 0.0896 \\
\hline Dominance (D) & 1.0896 \\
\hline Richness (R) & 11.6423 \\
\hline
\end{tabular}

From the overall data presentation and discussion, it is confirmed that results of previous scientists and researchers in different areas over the world were analogous to our present findings, but sometime deviations were recorded due to variations in ecological conditions and skill power, handling expertise and documentation of data [26, 27].

\section{Conclusion}

From the overall data it is concluded that diversity among different orders of insects is present. As hypothesized, diversity may vary among different orders it is noted that species varied of different insect orders while pretending significance of results.

\section{Compliance with ethical standards}

\section{Acknowledgments}

I gladly acknowledge to biodiversity lab, department of zoology wildlife and fisheries, University of Agriculture, Faisalabad for wholly contribution and providing all the needs in research work.

\section{Disclosure of conflict of interest}

The authors declare no conflict of interest.

\section{References}

[1] Richards OW. (1940). The biology of the small white butterfly (Pieris rapae), with special reference to the factors controlling its abundance. Journal of Animal Ecology, 9, 243-288.

[2] Puttker T, Bueno AA, Barros CDSD, Sommer S and Pardini R. (2013). Habitat specialization interacts with habitat amount to determine dispersal success of rodents in fragmented landscapes. Journal of Mammalogy, 94, 714726. 
[3] Gaston KJ. (2000). Global patterns in biodiversity. Nature, 405, 220-227.

[4] Thrupp LA. (2000). Linking agricultural biodiversity and food security: The valuable role of agrobiodiversity for sustainable agriculture. International affairs, 76(2), 283-297.

[5] Andersen AN. (1995). A classification of Australian ant communities based on functional groups which parallel plant life forms in relation to stress and disturbance. Journal of Biogeography, 22, 15-29.

[6] Chapman RF. (1998). The insects: Structure and function. New York, Cambridge University Press, 12-15.

[7] Paoletti MG, Pimentel D, Stinner BR and Stinner D. (1992). Agro-ecosystem biodiversity: Matching production and conservation biology. Agriculture Ecosystem and Environment, 40, 3-23.

[8] Kremen C, Colwell RK, Erwin TS, Murphy DD, Noss RF and Sanjayan MA. (1993). Terrestrial arthropod assemblages: their use in conservation planning. Conservation Biology, 7, 796-808.

[9] Booij CJH and Noorlander J. (1992). Farming systems and insect predators. Agriculture Ecosystem and Environment, 40, 125-135.

[10] Luff ML. (1983). The potential of predators for pest control. Agriculture, Ecosystems and Environment, 27, 241251.

[11] Siemann E, Tilman D, Haarstad J and Ritchie M. (1998). Experimental tests of the dependence of arthropod diversity on plant diversity. American Nature, 152, 738-750.

[12] Iperti G. (1999). Biodiversity of predaceous Coccinellidae in relation to bio indication and economic importance. Agriculture Ecosystems and Environment, 74, 323-342.

[13] Nentwig W, Frank T and Lethmayer C. (1998). Some weed strips artificial ecological compensation areas as an important tool in conservation biological control. In Barbosa, Conservation Biological Control, Academic Press, London, 133-156.

[14] Letourneau D. (1997). Plant arthropod interactions in agroecosystems. In: Jackson, L. Ecology in Agriculture, Academic Press San Diego. California, 239-290.

[15] Barbosa P. and Wratten SD. (1998). Influence of plants on invertebrate predator's implications to conservation biological control. In: Barbosa, P. Conservation Biological Control, Academic Press, London, 83-100.

[16] Lasalle J. (1999). Insect biodiversity in agroecosystems: Function, value and optimization. Agrobiodiversity: Characterization, Utilization and Management. CAB International Publication Wallingford, UK, 155-182.

[17] Thacker JRM. (2002). An introduction to arthropod pest control. Cambridge University Press, 1-337.

[18] Hooper DU. (2005). Effects of biodiversity on ecosystem functioning, a consensus of current knowledge. Ecological Monographs, 75, 3-35.

[19] Orie L. (1997). Emergence of research on agro-ecosystems. Annual Review of Ecology and Systematics, 8, 173192.

[20] Swift MJ, Vanderveer V, Ramakrishnan PS, Anderson JM, Ong CK and Hawkins BA. (1996). Biodiversity and agro ecosystem function. John Wiley and Sons Ltd., 261-298.

[21] Arshad S and Shafqat A. (2012). Food security indicators, distribution and techniques for agriculture sustainability in Pakistan. International Journal of Applied Science and Technology, 2, 137-147.

[22] Welbaum GE, Sturz AV, Dong ZM and Nowak J. (2004). Managing soil microorganisms to improve productivity of agroecosystems. Critical Review of Plant Science, 23: 175-193.

[23] Borror DJ and Delong DM. (2005). An introduction to the study of insects. Columbus, Ohio, 812.

[24] Magurran AE. (1988). Ecological diversity and its measurement. Princeton University Press, New Jersey, 34-37.

[25] Ludwig JA and James FR. (1988). Statistical ecology: A primer on methods and computing. Wiley International Publication, New York, 1-33.

[26] Aslam M. and Razaq M. (2007). Arthropod fauna of Brassica Napus and Brassica juncea from Southern Punjab (Pakistan). Journal of Agriculture and Urban Entomology, 24, 49-50.

[27] Balleras GD and Endonela LE. (2014). Aboveground arthropod composition, abundance and guild structure in upland rice agroecosystem at Matalam, North Cotabato, Philippines. International Peer Review Journal, 9, 61-76. 
[28] Veenakumari K Mohanraj P and Bandyopadhyay AK. (1997). Insects herbivores and their natural enemies in mangals of the Andaman and Nicobars Islands. Journal Natural History, 31, 1105-1126.

[29] Shannon CE. (1948). A mathematical theory of communication. Journal of Bell Systematic Technology, 27, 379423.

[30] Tewari M Poonam BD and Kaushal R. (2006). Diversity of terrestrial insects in a cultivated land of tarai region of Kumaun, Uttaranchal. Entomology, 31, 207-216.

\section{How to cite this article}

Rana N, Saleem M, Majeed W, Jalal F, Ehsan N and Nargis S. (2019). Diversity of arthropods regarding habitat specialty in agro-ecosystem of Faisalabad, Pakistan. GSC Biological and Pharmaceutical Sciences, 6(2), 01-08. 